\title{
Hepatic Iron Overload in Transfusion Dependent Chronic Hemolytic Anemic Patients: Where Does MRI R2* Relaxometry Stand?
}

\author{
WESSAM A. ELZAYAT, M.D. and MONA EL-KALIOUBIE, M.D. \\ The Department of Diagnostic and Intervention Radiology, Faculty of Medicine, Cairo University
}

\begin{abstract}
Background: Hepatic iron overload in pediatric population with repeated blood transfusion is an important morbidity warranting the evolution of a noninvasive method of liver iron quantification. MR T2*/R2* relaxometry technique has shown promising results in this domain.
\end{abstract}

Aim of Study: To show the value of MR T2*/R2* relaxometry technique, in assessment of hepatic iron overload in a sample pediatric patient population at our hospital on repeated blood transfusions therapy for thalassemia and sickle cell anemia.

Patients and Methods: A total of 44 patients, mean age 11.14 \pm 3.38 (range: 6-17 years old) patients with thalassemia and sickle cell anemia who had received more than 20 blood transfusions and on chelation therapy at the time of the examination, underwent MRI T2*/R2* relaxometry study. The corresponding iron overload was calculated for each patient, then correlation between R2* and serum ferritin level was done by using Pearson's correlation coefficient.

Results: Serum ferritin levels ranged between 56.7 and $11524 \mathrm{ng} / \mathrm{mL}$ (mean $3605.8 \mathrm{ng} / \mathrm{mL}$ ). R2* values ranged between 77.1 and $11426 \mathrm{~Hz}$ (mean $2361 \mathrm{~Hz}$ ). Based on the calculated Liver Iron Concentrations (LIC) values which ranged between 0.47 and $42.55 \mathrm{mg} / \mathrm{g}$ (mean $11.38 \mathrm{mg} / \mathrm{g}$ ) 9 patients $(20.45 \%$ ) showed normal hepatic iron load, 10 patients $(22.73 \%)$ showed mild iron overload, 13 patients $(29.55 \%)$ showed moderate overload and 12 patients $(27.27 \%)$ showed severe overload. The correlation between R2* and serum ferritin was a weak positive one with a Pearson's coefficient of $0.49(p=0.000645)$ The correlation between LIC and serum ferritin was a moderate positive one with a Pearson's correlation of 0.5 ( $p=0.000494)$

Conclusion: Quantification of liver iron deposition in children with chronic hemolytic anemia receiving multiple blood transfusions is empirical for chelation therapy monitoring. R2* relaxometry shows promising results as an effective quantitative tool for estimation of hepatic iron overload when compared to serum ferritin levels, therefore providing a safer alternative in contrast to tissue biopsy.

Key Words: Chronic hemolytic anemia - Iron overload Liver MRI.

Correspondence to: Dr. Wessam A. Elzayat, E-Mail: wessamzayat@yahoo.com

\section{Introduction}

HEPATIC iron overload is a major complication of repeated therapeutic blood transfusions in children with chronic hemolytic anemia. It is a highrisk factor for liver morbidity, damage and even mortality. Therefore, it has to be carefully followed and monitored to decide on and adjust proper timing of effective chelation [1]

Liver iron levels are known to mirror the total body iron contents with a proportionate relationship [2]

In the pediatric population, in particular, a noninvasive quantification of hepatic iron load is a must [3] . Traditionally, non-targeted percutaneous hepatic biopsy has been the method of choice for such assessment, however it is invasive, risky and suffers from sampling variability [4-7]. Other techniques such as measurement of liver magnetic susceptibility with a Superconducting Quantum Interference Device (SQUID) [8,9], ultrasound, CT and dual energy CT [10,11] are not optimal for repeated iron load calculations [1]

MRI based evaluation has shown promising results by exploring the paramagnetic properties of iron in tissue with macroscopic modifications in $\mathrm{B} 0$ as well as the signal changes induced by ferritin and hemosiderin characterized by $\mathrm{T} 1, \mathrm{~T} 2$ and T2* relaxation time shortening [1,12]. Different MR strategies have been proposed for both qualitative and quantitative assessment of hepatic iron, including signal intensity (liver/paraspinal muscles) ratio, quantitative relaxometry and MR susceptometry $[10,13-17]$.

The aim of this study is to show the impact of MR T2*/R2* relaxometry technique, as regards to its methodology, usefulness, limitations and remaining challenges in a sample pediatric patient 
population at our hospital. Our reference standard is the laboratory serum marker (serum ferritin) which has remained the method of diagnosis and deciding marker for chelation therapy initiation or modification at our institution.

\section{Patients and Methods}

\section{Patients:}

The study was approved by our Hospital's Ethical Committee. We included a total of 44 patients ( 21 boys/23 girls), mean age $11.14 \pm 3.38 \mathrm{SD}$ (range: 6-17 years old). They were referred to our Radiology Department in Children's Hospital (Abu Elreesh) for MRI evaluation of liver iron load between April and November 2019.

\section{Inclusion criteria were:}

1- Patients with thalassemia $(n=32)$ and sickle cell anemia $(n=12)$.

2- Patients that have received more than 20 blood transfusions.

3- Patients receiving chelation therapy at the time of the examination. We excluded patients with established liver fibrosis, inflammation or steatosis to optimize our MRI technique performance since the presence of such pathologies might decrease the sensitivity of $\mathrm{R} 2 *$ relaxation to iron overload $[\mathbf{1 8 , 1 9 ]}$

\section{MRI examination protocol:}

We used our 1.5 Tesla Siemens MRI machine (MAGNETOM Aera, Erlangen, Germane) for all patients. To measure the hepatic $\mathrm{T} 2 *$ relaxation time, a single axial mid-hepatic (at the main portal vein origin) multiecho fast gradient-echo MFGRE $\mathrm{T} 2 *$ sequence was performed.

The parameters used were: Breath-hold acquisition in compliant children (no breath-holding in younger and non-compliant ones), flip angle $20^{\circ}$, FOV 30 , slice thickness $10 \mathrm{~mm}, 4$ regularly spaced echo times from $1.2 \mathrm{~ms}-25.8 \mathrm{~ms}$, TR $200 \mathrm{~ms}, 1$ excitation, matrix $96 / 96$, bandwidth $83 \mathrm{kHz}$, acquisition time $21 \mathrm{~s}$.

Post-processing calculations were done on the Siemens MMWP Multi Modalities workplace. For each patient, a region of interest was drawn within the right liver lobe on $\mathrm{T} 2 *$ maps, excluding any vasculature. Once the relaxation time $\mathrm{T} 2 *$ value was obtained in $\mathrm{ms}$, we converted it to the relaxation rate $\mathrm{R} 2 *$, its reciprocal $(\mathrm{R} 2 *=1000 / \mathrm{T} 2 *)$ in $\mathrm{Hz}$ since the latter is directly proportional to the Liver Iron Concentration (LIC).
A signal decay curve was also obtained for each case showing progressive decay of liver signal with the echo times.

Then we used the established Wood's formula [15] to calculate the corresponding liver iron load to each $\mathrm{R} 2 *$ value for all patients ( $\mathrm{Fe} \mathrm{mg} / \mathrm{g}=\mathrm{R} 2$ * X 0.0254+0.202).

We used the following cut-off values to grade the liver iron concentration and hence iron hepatic overload, based on Garbowski MW, et al., study [20]:

- $T 2 *$ : Normal: $>11.4 \mathrm{~ms}$, Light: $3.8-11.4 \mathrm{~ms}$, Moderate: $1.8-3.8 \mathrm{~ms}$, Severe: $<1.8 \mathrm{~ms}$.

- $R 2 *$ : Normal: $<88 \mathrm{~Hz}$, Light: 88-263Hz, Moderate: 263-555Hz, Severe: $>555 \mathrm{~Hz}$.

- LIC: Normal: $<2 \mathrm{mg} / \mathrm{g}$, Light: $2-7 \mathrm{mg} / \mathrm{g}$, Moderate: $7-15 \mathrm{mg} / \mathrm{g}$, Severe: $>15 \mathrm{mg} / \mathrm{g}$.

\section{Reference standard:}

We obtained the serum ferritin levels for the study population from patients' files. Hyperferritinemia was considered when serum ferritin levels exceeded $140 \mathrm{ng} / \mathrm{mL}$ [21].

\section{Statistical analyses:}

The SPSS software (Statistical Package for the Social Science; SPSS Inc., Chicago, IL, USA), release 21 Versions for Mac was used. Mean \pm Standard Deviation (SD) or number/percentage (\%) were used for data expression. Correlation between R2* and serum ferritin level was done by using Pearson's correlation coefficient.

The $p$-values by Chi-square test were determined: $<0.05=$ significant, $<0.01=$ highly significant and $>0.05=$ non-significant.

\section{Results}

Forty-four patients were included in this study, 21 males and 23 females. Patients' age ranged between 6 and 17 years; mean age, $11.14 \pm 3.38$ SD.

All patients were under chelation treatment at the time of the study.

Serum ferritin levels ranged between 56.7 and $11524 \mathrm{ng} / \mathrm{mL}$ (mean $3605.8 \mathrm{ng} / \mathrm{mL}$ ).

The $\mathrm{T} 2 *$ values ranged between 0.4 and $66.7 \mathrm{~ms}$ (mean 10.28ms \pm 14.4SD).

The R2* values ranged between 77.1 and 11426 $\mathrm{Hz}$ (mean 2361Hz). 
Based on the calculated LIC values which ranged between 0.47 and $42.55 \mathrm{mg} / \mathrm{g}$ (mean 11.38 $\mathrm{mg} / \mathrm{g}$ ) 9 patients (20.45\%) showed normal LIC, 10 patients $(22.73 \%)$ showed mild LIC, 13 patients (29.55\%) showed moderate LIC Fig. (1) and 12 patients $(27.27 \%)$ showed severe LIC.
The correlation between R2* and serum ferritin was a weak positive one with a Pearson's coefficient of 0.49 ( $p=0.000645)$ Diagram (1).

The correlation between LIC and serum ferritin was a moderate positive one with a Pearson's correlation of 0.5 ( $p=0.000494)$ Diagram (2).
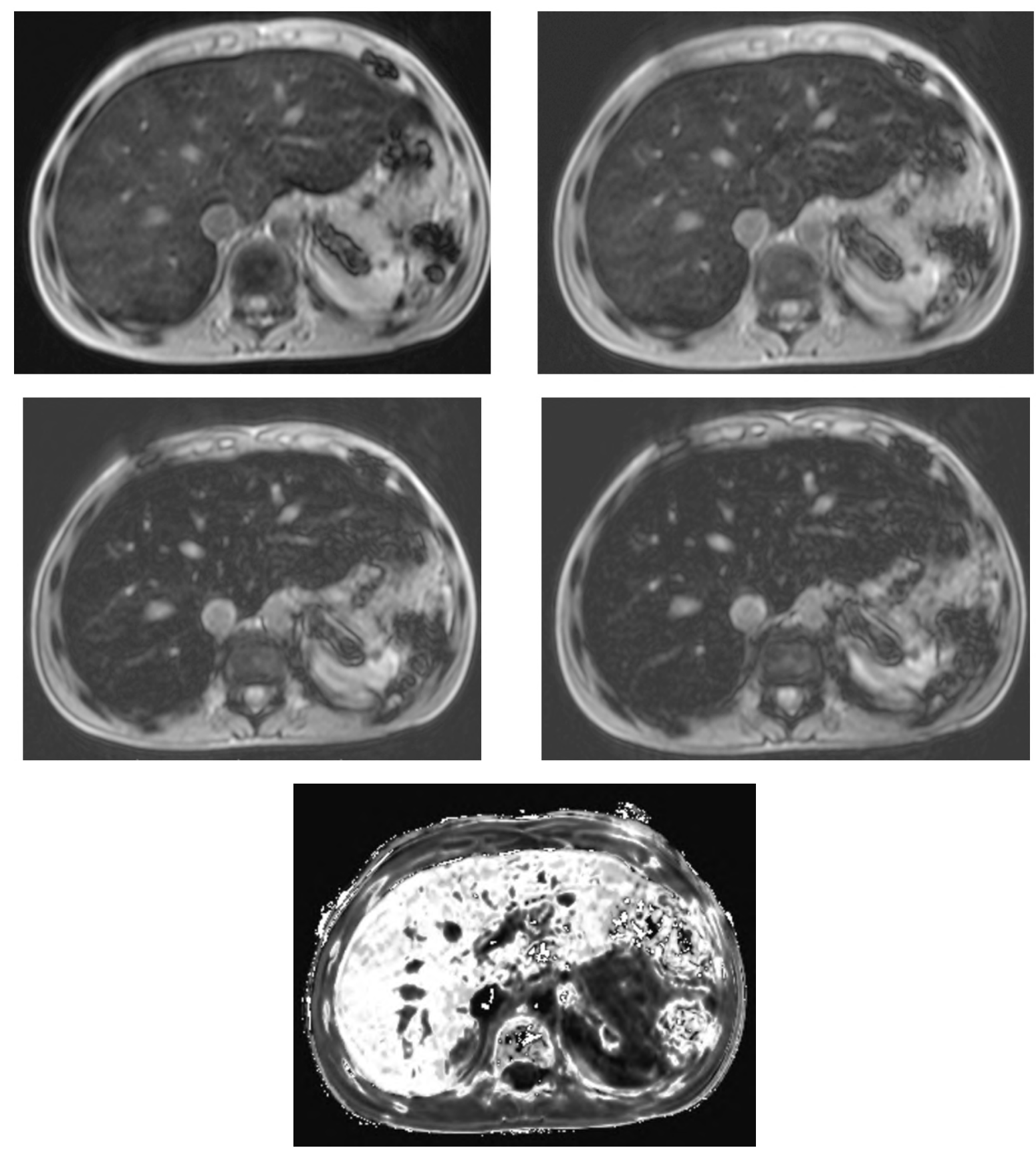

Fig. (1): Hepatic MRI, MFGRE sequence, top row: Images of the 4 initial echoes. There is rapid decay in the signal in the liver. The $\mathrm{T} 2 *$ is $4.2 \mathrm{~ms}$. Bottom row: $\mathrm{R} 2 *$ mapping: The $\mathrm{R} 2 *$ is $97 \mathrm{~Hz}$, which corresponds to $7.43 \mathrm{mg} \mathrm{Fe} / \mathrm{g}$ dry liver, indicating moderate iron overload. 


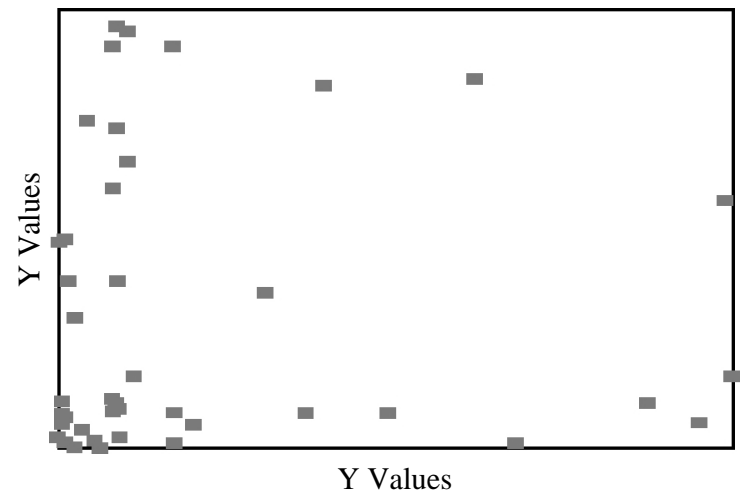

Diagram (1): Weak positive correlation between $\mathrm{R} 2 *$ (x axis) and serum ferritin (y axis).

\section{Discussion}

Estimation of hepatic iron load is mandatory in the pediatric population receiving repeated blood transfusions for chronic hemolytic anemia. Previously considered the procedure of choice for liver iron quantification, hepatic tissue biopsy is invasive and not without risks, warranting the need for a safer alternative [2] .

Furthermore, serum ferritin alone is not completely reliable to assess liver iron overload since it is often subjected to variations related to pathological conditions such as infection, inflammation, and chronic diseases. Also, cases of severe iron overload with mismatching low serum ferritin levels have been reported [7].

The role of MRI T2* in assessment of LIC has been illustrated in several studies [5-7,10-12,14,15]

We analyzed the diagnostic role and accuracy of MRI R2* relaxometry and correlated it with serum ferritin levels.

We included 44 patients with chronic hemolytic anemia ranging between 6 and 17 years old, under chelation therapy.

Serum ferritin levels ranged between 56.7 and $11524 \mathrm{ng} / \mathrm{mL}$ (mean 3605.8ng/ml).

In the study done by Fahmy HS et al., on 70 patients with $\mathrm{B}$ thalassemia and sickle cell anemia serum ferritin ranged between 301 and 12927 [12] Median serum ferritin was $2001 \mathrm{ng} / \mathrm{ml}$ (ranging between 94 and 16927), in Verlhac S et al., study done on 68 children who mainly received transfusion for sickle cell anemia [3].

Our population $\mathrm{T} 2 *$ values ranged between 0.4 and $66.7 \mathrm{~ms}$ (mean $10.28 \mathrm{~ms} \pm 14.4 \mathrm{SD}$ ), and the reciprocal $\mathrm{R} 2 *$ values ranged between 77.1 and $11426 \mathrm{~Hz}$ (mean $2361 \mathrm{~Hz}$ ). The subsequent LIC

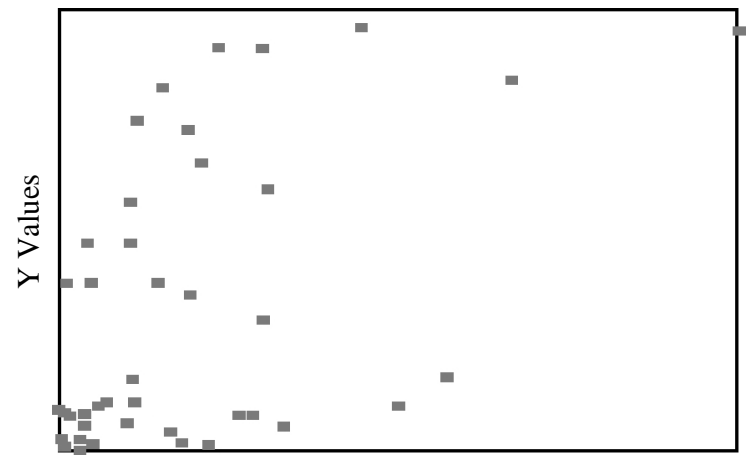

Y Values

Diagram (2): Moderate positive correlation between LIC (x axis) and serum ferritin (y axis).

values ranged between 0.47 and $42.55 \mathrm{mg} / \mathrm{g}$ (mean $11.38 \mathrm{mg} / \mathrm{g})$.

The correlation between R2* and serum ferritin was a weak positive one with a Pearson's coefficient of $0.49(p=0.000645)$.

Eghbali et al., and Christoforidis studies showed a strong positive correlation between hepatic $\mathrm{T} 2$ * MRI and serum ferritin levels [27,28] .

We found that the correlation between LIC and serum ferritin was a moderate positive one with a Pearson's correlation of 0.5 ( $p=0.000494)$.

Verlhac et al., also found an existing correlation between LIC and serum ferritin ( $r=0.553, p<0.001)$, as well as between LIC and the number of transfusions $(r=0.350, p=0.001)$ [3]. As did several other studies [24-27].

This is in disconcordance with Fahmy et al., study who reported a significant negative correlation between liver T2* MRI and serum ferritin levels [12].

Verlhac et al., compared $\mathrm{R} 2 *$ relaxometry $(\mathrm{R} 2 *=$ $1000 / \mathrm{T} 2 *$ ) to the reference technique liver/muscle Signal Intensity Ratio (SIR). However, with the advances in multiecho-GRE sequences, SIR is now seen as less accurate than R2* relaxometry in the setting of mild and moderate iron overload [22] Furthermore, it requires multiple breath-holding acquisitions, clearly not suitable for pediatric patients $[\mathbf{1 5 , 2 3 ]}$.

Quantification of liver iron deposition in children with chronic hemolytic anemia receiving multiple blood transfusions is empirical for chelation therapy monitoring. R2* relaxometry shows promising results as an effective quantitative tool for estimation of hepatic iron overload when compared to serum ferritin levels, providing a safer alternative in contrast to tissue biopsy. 


\section{References}

1- HERNANDO D., LEVIN Y.S., SIRLIN C.B., et al.: Quantification of Liver Iron with MRI: State of the Art and Remaining Challenges. J. Magn. Reson. Imaging, 40 (5): 1003-21, 2014.

2- BRITTENHAM G.M. and BADMAN D.G.: Noninvasive measurement of iron: Report of an NIDDK workshop. Blood, 101: 15-9, 2003.

3- VERLHAC S., MOREL M., BERNAUDIN F., et al.: Liver iron overload assessment by MRI R2* relaxometry in highly transfused pediatric patients: An agreement and reproducibility study. Diagnostic and Interventional Imaging, 96: 259-64, 2015.

4- EMOND M.J., BRONNER M.P., CARLSON T.H., et al.: Quantitative study of the variability of hepatic iron concentrations. Clin. Chem., 45: 340-6, 1999.

5- KREEFTENBERG H.G., KOOPMAN B.J., HUIZENGA J.R., et al.: Measurement of iron in liver biopsies--a comparison of three analytical methods. Clin. Chim. Acta, 144: 255-62, 1984.

6- BRAVO A.A., SHETH S.G. and CHOPRA S.: Liver biopsy. N. Engl. J. Med., 344: 495-500, 2001.

7- COPEL L., SOSNA J. and KRUSKAL J.B.: Ultrasoundguided percutaneous liver biopsy: Indications, risks, and technique. Surg. Technol. Int., 11: 154-60, 2003.

8- BRITTENHAM G.M., FARRELL D.E., HARRIS J.W., et al.: Magnetic-susceptibility measurement of human iron stores. N. Engl. J. Med., 307: 1671-5, 1982.

9- ALUSTIZA J.M., CASTIELLA A., De JUAN M.D., et al.: Iron overload in the liver diagnostic and quantification. Eur. J. Radiol., 61: 499-506, 2007.

10- GANDON Y., OLIVIE D., GUYADER D., et al.: Noninvasive assessment of hepatic iron stores by MRI. Lancet, 363: 357-62, 2004

11-FISCHER M.A., REINER C.S., RAPTIS D., et al.: Quantification of liver iron content with CT-added value of dual-energy. Eur. Radiol., 21: 1727-32, 2011.

12- FAHMY H.S., KHATER N.H., EL SHAHAT H.M., et al.: Reassessing the value of MRI T2* in evaluation of hepatic and myocardial iron concentration: An institutional study. The Egyptian Journal of Radiology and Nuclear Medicine, 46: 1085-90, 2015.

13- ALUSTIZA J.M., EMPARANZA J.I., ALDAZABAL P., et al.: Standardization of the quantification of iron concentration in the liver by magnetic resonance imaging. Radiologia, 54: 149-54, 2012.

14- VIRTANEN J.M., KOMU M.E. and PARKKOLA R.K.: Quantitative liver iron measurement by magnetic resonance imaging: In vitro and in vivo assessment of the liver to muscle signal intensity and the R2* methods. Magn. Reson. Imaging, 26: 1175-82, 2008.

15- WOOD J.C., ENRIQUEZ C., GHUGRE N., et al.: MRI $\mathrm{R} 2$ and $\mathrm{R} 2 *$ mapping accurately estimates hepatic iron concentration in transfusion-dependent thalassemia and sickle cell disease patients. Blood, 106: 1460-5, 2005.

16- HOLT R.W., DIAZ P.J., DUERK J.L., et al.: MR susceptometry: An external-phantom method for measuring bulk susceptibility from field-echo phase reconstruction maps. J. Magn. Reson. Imaging, 4: 809-818, 1994.

17- CHU Z., COHEN A.R., MUTHUPILLAI R., et al.: MRI measurement of hepatic magnetic susceptibility-phantom validation and normal subject studies. Magn. Reson. Med., 52: 1318- 27, 2004.

18- CARNEIRO A.A., FERNANDES J.P., De ARAUJO D.B., et al.: Liver iron concentration evaluated by two magnetic methods: Magnetic resonance imaging and magnetic susceptometry. Magn. Reson. Med., 54: 122-8, 2005.

19- TAOULI B. and KOH D.M.: Diffusion-weighted MR imaging of the liver. Radiology, 254: 47-66, 2010.

20- GARBOWSKI M.W., CARPENTER J., SMITH G., et al.: Biopsy-based calibration of T2* magnetic resonance for estimation of liver iron concentration and comparison with R2 Ferriscan. J. Cardiovasc. Magn. Reson., 16: 40, 2014.

21- "Ferritin". WebMD. Retrieved 27 October 2016.

22- HENNINGER B., ALUSTIZA J., GARBOWSKI M., et al.: Eur. Radiol. https://doi.org/10.1007/s00330-01906380-9, 2019.

23- HANKINS J.S., McCARVILLE M.B., LOEFFLER R.B. SMELTZER M.P., ONCIU M., HOFFER F.A., et al.: R2* magnetic resonance imaging of the liver in patients with iron overload. Blood, 113: 4853-5, 2009.

24- RUCCIONE K.S., J.C. WOOD, R. SPOSTO, J. MALVAR, C. CHEN and D.R. FREYER: Characterization of transfusion-derived iron deposition in childhood cancer survivors. Cancer Epidemiology and Prevention Biomarkers, cebp. 0292.2014, 2014.

25- SCHEMPP A., J. LEE, S. KEARNEY, D.A. MULROONEY and A.R. SMITH: Iron overload in survivors of childhood cancer. Journal of pediatric hematology/oncology, 38, (1) 27-31, 2016.

26- VAG T., K. KENTOUCHE, I. KRUMBEIN, J.R. REICHENBACH, E. LOPATTA, D.M. RENZ, M. STENZEL, J. BECK, W.A. KAISER and H.J. MENTZEL: Noninvasive measurement of liver iron concentration at MRI in children with acute leukemia: Initial results. Pediatric radiology, 41, (8) 980, 2011.

27- EGHBALI A., H. TAHERAHMADI, M. SHAHBAZI, B BAGHERI and L. EBRAHIMI: Association between serum ferritin level, cardiac and hepatic T2-star MRI in patients with major $\beta$-thalassemia. Iranian journal of pediatric hematology and oncology, 4, (1) 17, 2014.

28- CHRISTOFORIDIS, A. HARITANDI, I. TSITOURIDIS, et al.: Correlative study of iron accumulation in liver, myocardium and pituitary assessed with MRI in young thalassemic patients. J. Pediatr. Hematol. Oncol., 28: pp. 311-5, 2006. 


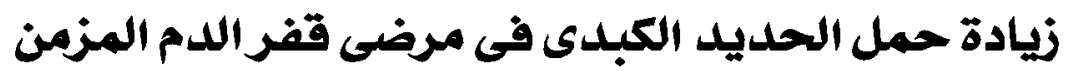

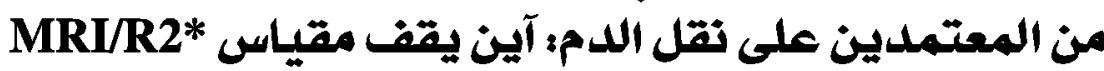

الهدف: لإظهار قيمة تقنية لقياس MR T2*/R2* الإسترخاء، فى تقييم الحمل الزائد للصديد الكبدى للىى عينة من المرضى من الآطفال

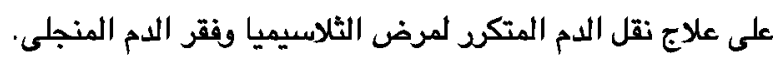

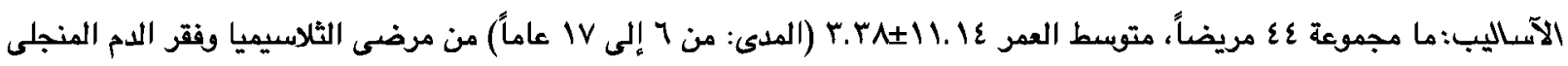

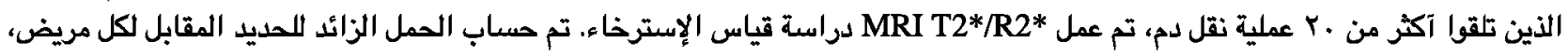

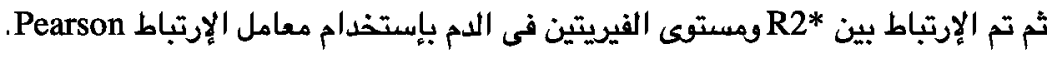

النتائج: تراوحت قيم R2 بين IV.

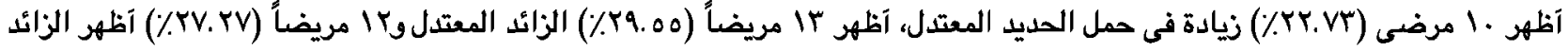

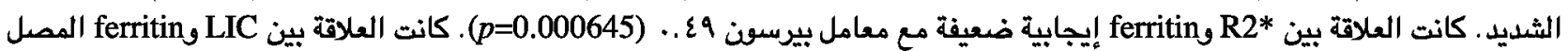
إيجابية معتدلة مع إرتباط بيرسون (1) (p=000494)

الخلاصة: يُظهر قياس الإسترخاء R2* نتائج واعدة كاداة فعالة لتقدير الحمل الزائد من الحديد الكبدى عند مقارنته بمستويات فيريتين

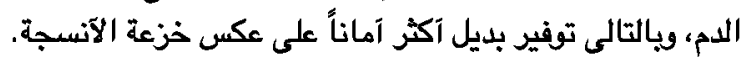

